\title{
Unusual Feeding Behaviour of Chickadee
}

\author{
by Robert W. Nero, Regina
}

A biological niche which I had not previously noticed was recently called to my attention by the foraging behaviour of a Black-capped Chickadee. On October 2, 1961, in the middle of the afternoon, while driving along a country road some six miles northwest of Regina and within a quarter of a mile of the wooded Wascana Creek valley, we found a chickadee feeding on the tops of wooden fence posts. When we first saw the bird it was perched on a post in a fence line which ran right beside the road; since the situation provided a nice opportunity for the entire family to look at a chickadee we stopped to watch it. In a moment the bird flew to the top of the next post in line, so we drove slowly alongside again for another look. During the next several minutes we followed the chickadee as it flew from one post to another, heading north along the roadside fence, for about a quarter of a mile. It spent a few seconds, less than a minute usually, at nearly every post, evidently searching for food, especially on the top of the post. Each time it flew it dipped down low, then soared up again to land on the next post. It was especially interesting to note that it skipped the few iron fence posts which were in the line and occasionally it flèw past very small wooden posts, but otherwise it foraged on practically every post. Eventually the chickadee left the fence line in favor of a telephone pole circuit which joined the fence, the higher poles evidently being more to its liking. We finally stopped following the bird but noted that it continued north along the line of telephone poles as long as we watched, dropping down low then abruptly rising up again to land on the next pole and so on. A second chickadee was shortly seen foraging in a similar way on a nearby line of telephone poles.

We stopped to examine a few posts in an adjacent fence in order to learn what the chickadee might have been feeding on. Some small live spiders, a common food of the chickadee ac- cording to the Bent "Life history" series (Bulletin 191), were found on a few post tops. In addition, nearly every post top had a quantity of old bird feces, often containing insect remains, but it seemed to me that these would be low in food value. Spiders and :small insects were presumably the main attraction for the chickadee. The afternoon sun may have warmed the post tops as well as the spiders which found this a useful area in which to hunt their prey, thus providing this unusual niche for the chickadee to exploit. Although the chickadee primarily searches for food in woods and brush the fence-post niche may provide a useful supplementary source of food, especially on the prairies.

\section{PREDATORY CROW}

\section{by Bernard C. Haysom, Regina}

On September 1, 1962, while travelling west on \#1 Highway, Johan Toews and I sighted a small flock of swallows perched on telephone wires and on a pole about one mile west of Ernfold ( 45 miles east cf Swift Current). A moment later we noticed two crows heading toward the pole on which the swallows were sitting and, as we expected, the swallows soon took flight. Noticing a fluttering movement on the far side cf one of the cross-arms, I thought that one of the crows had missed its target and was caught on the pole or on a wire. All this was observed as we approached at highway speed. As we passed this particular pole, I turned in my seat to see just what had happened. To my surprise, I saw that the crow was perched on the crossarm "support with a struggling swallow clutched firmly in one foot. Unfortunately, with the surprise and being on \#1 Highway, Johan was unable to stop. Thus we are uncertain of the species and age of the swallow. Because the telephone pole obscured my vision, I was unable to see the actual capture. 